\title{
A Case of Fulminant Type 1 Diabetes with Gastric and Urinary Retention
}

Chuan Xing $\cdot$ Wenqian Zhao $\cdot$ Yanjun Wang

Received: September 17, 2018 / Published online: November 20, 2018

(C) The Author(s) 2018

\begin{abstract}
Fulminant type 1 diabetes (fT1D) is a severe subtype of type 1 diabetes which progresses rapidly with islet cells destroyed almost completely within a short period of time. It is often characterized by flu-like or gastrointestinal symptoms at the onset with negative islet-associated autoantibodies, resulting in an absolute deficiency of endogenous insulin secretion. Poor prognosis can be caused by the significantly higher incidence of metabolic disorders (such as severe ion disorders and elevated serum pancreatic enzymes), acute and chronic complications if not diagnosed and treated in a timely manner. We herein describe an fT1D patient with gastric and urinary retention along with severe ion disturbance, whose laboratory tests revealed diabetic ketoacidosis, peripheral neuropathy, retinopathy, nephropathy, and hypoproteinemia.
\end{abstract}

Enhanced Digital Features To view enhanced digital features for this article go to https://doi.org/10.6084/ m9.figshare.7296998.

C. Xing · W. Zhao $\cdot$ Y. Wang $(\bowtie)$

First Endocrinology Department, Shengjing

Hospital Affiliated to China Medical University,

Shenyang, People's Republic of China

e-mail: wangyjsy@163.com
Keywords: Diagnosis; fT1D; Gastric and urinary retention; Pathogenesis; Treatment

\section{CASE REPORT}

A 67-year-old Chinese woman was referred to our hospital with swallowing difficulty and nausea for 2 weeks, palpitation and frequent urination for 3 days. Informed consent was obtained from her for being included in the study.

The patient complained of a sensation of foreign body and obstruction in the pharynx, and a feeling of fullness after meals accompanied by nausea and suffocation. Symptoms worsened 3 days prior to admission, the patient could no longer eat, and her urine volume increased significantly. One day before admission, laboratory tests showed blood potassium was $2.44 \mathrm{mmol} / \mathrm{l}$, and a potassium supplement was given. Gastroscopy showed that flat erosive gastritis covered with plenty of brittle white purulent secretions and gastric retention. The patient had a partial thyroidectomy for thyroid mass 30 years ago. At admission, fingertip blood glucose was $23.5 \mathrm{mmol} / \mathrm{l}$. Physical examination showed $T 36.5^{\circ} \mathrm{C}$, pulse 93 beats $/ \mathrm{min}$, respiratory rate 26 beats/min, BP 104/66 $\mathrm{mmHg}$, height $1.56 \mathrm{~m}$, weight $50 \mathrm{~kg}$, BMI $20.55 \mathrm{~kg} / \mathrm{m}^{2}$. The patient was dehydrated with poor skin elasticity, breathing heavily with mild edema of the lower limbs. Biochemistry tests showed 
elevated WBC, NE, and CRP (C-reactive protein) indicating bacterial infection; routine urine analysis showed high levels of bacteria and WBC while urine culture found growth of faecium indicating urinary tract infection. Gastroscopy showed flat erosive gastritis covered with plenty of brittle white purulent secretions, and feces culture found growth of albicans indicating gastrointestinal tract infection; blood glucose was elevated significantly while $\mathrm{pH}$ and bicarbonate decreased significantly along with urine routine showed urine protein $2+$, glucose $4+$, ketone body $4+$ indicating diabetic ketoacidosis which was probably induced by gastrointestinal tract and urinary tract infection; albumin and potassium were low indicating hypoproteinemia and hypokalemia; urine microalbumin/urinary creatinine and $24 \mathrm{~h}$ urine protein quantity were elevated significantly indicating severe diabetic nephropathy; blood glucose and glycated albumin were elevated significantly while glycated hemoglobin was elevated slightly with low levels of serum C-peptide indicating short course of disease with large fluctuations of blood glucose owing to islet beta cells being rapidly and almost completely destroyed; type 1 diabetes autoantibody (GAD, IA2A, ZnT-8A, ICA, IAA) and antinuclear antibody series were negative. Related biochemical parameters over time are shown in Table 1. Electromyography showed peripheral nerve damage with feeling and motor fibers both remained. Fundus photography showed hemorrhage and exudation in the posterior thin pole retinal arteries. Abdominal CT showed that the gastric antrum wall was thickened because of edema, the bladder wall was thickened with multiple diverticula, and abdominal and pelvic fluid existed with no abnormality on the pancreatic image. Urinary system ultrasound showed chronic cystitis with urinary retention. The patient was diagnosed with fT1D presenting with diabetic ketoacidosis, diabetic peripheral neuropathy, binocular diabetic retinopathy, diabetic nephropathy stage IV, esophagitis, gastric retention, hypokalemia, hypoproteinemia, urinary tract infection, chronic cystitis and urinary retention. The patient was given a large amount of fluid with small doses of insulin intravenous pumping to correct ketoacidosis along with treatments of potassium supplementation, acid-suppression, anti-inflammation, and albumin supplementation. The patient was then given insulin glargine $10 \mathrm{U}$ at bedtime every night and insulin aspart $6 \mathrm{U}$ before each meal to control blood sugar shortly after ketoacidosis was corrected. Symptoms such as dysphasia, frequent urination, and polyuria gradually relieved after 2 weeks. Fundus laser treatment, nerve nutritional treatment, and treatment to improve microcirculation were also used to improve the symptoms. The gastroscopy and urinary system ultrasound after about 1 month of treatment revealed that gastric and urinary retention disappeared with no organic lesions (Figs. 1, 2, 3). As a result of repeated hypoglycemia, the insulin glargine was gradually reduced to $7 \mathrm{U}$ every night and insulin aspart was reduced to $5 \mathrm{U}$, $5 \mathrm{U}$, and $4 \mathrm{U}$ before each meal to control blood sugar when she was discharged from the hospital.

\section{DISCUSSION AND CONCLUSION}

Fulminant type 1 diabetes is a severe subtype of type 1 diabetes first introduced by Imagawa in 2000 with islet beta cells rapidly and almost completely destroyed in a short period of time leading to an absolute lack of endogenous insulin secretion. The islet-associated autoantibodies are usually negative with significantly high incidence of metabolic disorders, acute and chronic complications accompanied by severe ion disorders and elevated serum pancreatic enzymes [1]. Criteria for definite diagnosis of fT1D set by the Japan Diabetes Society (JDS) in 2012 include (1) occurrence of diabetic ketosis or ketoacidosis soon (approximately 7 days) after the onset of hyperglycemic symptoms (elevation of urinary and/or serum ketone bodies at first visit), (2) plasma glucose level $\geq 16.0 \mathrm{mmol} / \mathrm{l}(\geq 288 \mathrm{mg} / \mathrm{dl})$ and glycated hemoglobin level $<8.5 \%$ (JDS value) at first visit, (3) urinary C-peptide excretion $<10 \mu \mathrm{g} /$ day or fasting serum C-peptide level $<0.3 \mathrm{ng} / \mathrm{ml}(<0.10 \mathrm{nmol} / \mathrm{l})$ and $<0.5 \mathrm{ng} /$ $\mathrm{ml}(<0.17 \mathrm{nmol} / \mathrm{l})$ after intravenous glucagon (or after meal) load at onset [2]. fT1D is 
Table 1 Biochemistry parameters

\begin{tabular}{|c|c|c|}
\hline Test & Result (date) & Normal range \\
\hline \multicolumn{3}{|c|}{ Routine blood analysis } \\
\hline \multirow[t]{2}{*}{ WBC } & $\begin{array}{r}17.0 \times 10^{9} / 1 \\
(2018.04 .25)\end{array}$ & $3.5-9.7 \times 10^{9} / 1$ \\
\hline & $\begin{array}{l}7.0 \times 10^{9} / 1 \\
(2018.04 .28)\end{array}$ & \\
\hline \multirow[t]{2}{*}{$\mathrm{NE}$} & $\begin{array}{l}15.5 \times 10^{9} / 1 \\
(2018.04 .25)\end{array}$ & $1.9-7.2 \times 10^{9} / 1$ \\
\hline & $\begin{array}{l}5.5 \times 10^{9} / 1 \\
(2018.04 .28)\end{array}$ & \\
\hline \multirow[t]{3}{*}{ CRP } & $\begin{array}{l}34.4 \mathrm{mg} / \mathrm{l} \\
\quad(2018.04 .25)\end{array}$ & $0-8 \mathrm{mg} / \mathrm{l}$ \\
\hline & $\begin{array}{l}10.4 \mathrm{mg} / \mathrm{l} \\
\quad(2018.04 .28)\end{array}$ & \\
\hline & $\begin{array}{l}6.1 \mathrm{mg} / \mathrm{l} \\
\quad(2018.05 .02)\end{array}$ & \\
\hline \multirow[t]{3}{*}{ Albumin } & $\begin{array}{l}34.8 \mathrm{~g} / 1 \\
\quad(2018.04 .25)\end{array}$ & $35-53 \mathrm{~g} / \mathrm{l}$ \\
\hline & $\begin{array}{l}24.0 \mathrm{~g} / \mathrm{l} \\
\quad(2018.05 .14)\end{array}$ & \\
\hline & $\begin{array}{l}28.1 \mathrm{~g} / 1 \\
\quad(2018.05 .21)\end{array}$ & \\
\hline \multirow[t]{3}{*}{ Potassium } & $\begin{array}{l}2.71 \mathrm{mmol} / \mathrm{l} \\
(2018.04 .25)\end{array}$ & $3.5-5.5 \mathrm{mmol} / \mathrm{l}$ \\
\hline & $\begin{array}{l}2.49 \mathrm{mmol} / \mathrm{l} \\
(2018.04 .26)\end{array}$ & \\
\hline & $\begin{array}{l}4.43 \mathrm{mmol} / \mathrm{l} \\
(2018.05 .02)\end{array}$ & \\
\hline \multicolumn{3}{|c|}{ Blood gas analysis } \\
\hline \multirow[t]{3}{*}{$\mathrm{PH}$} & $\begin{array}{l}7.045 \\
\quad(2018.04 .25)\end{array}$ & $7.35-7.45$ \\
\hline & $\begin{array}{l}7.319 \\
(2018.04 .26)\end{array}$ & \\
\hline & $\begin{array}{l}7.415 \\
\quad(2018.04 .27)\end{array}$ & \\
\hline
\end{tabular}

Table 1 continued

\begin{tabular}{lcc}
\hline Test & Result (date) & Normal range \\
\hline $\mathrm{HCO}_{3}{ }^{-}$ & $4.7 \mathrm{mmol} / \mathrm{l}$ & $22.0-26.0 \mathrm{mmol} /$ \\
& $(2018.04 .25)$ & 1 \\
& $15.0 \mathrm{mmol} / \mathrm{l}$ & \\
& $(2018.04 .26)$ & \\
& $24.2 \mathrm{mmol} / \mathrm{l}$ & \\
& $(2018.04 .27)$ &
\end{tabular}

Routine urine analysis

\begin{tabular}{|c|c|c|}
\hline \multirow[t]{4}{*}{ Protein } & $2+(2018.04 .25)$ & Negative \\
\hline & $1+(2018.04 .26)$ & \\
\hline & $\begin{array}{l}\text { Negative } \\
\qquad(2018.05 .02)\end{array}$ & \\
\hline & $\begin{array}{l}\text { Negative } \\
\qquad(2018.05 .21)\end{array}$ & \\
\hline \multirow[t]{4}{*}{ Glucose } & $4+(2018.04 .25)$ & Negative \\
\hline & $3+(2018.04 .26)$ & \\
\hline & $\begin{array}{l}\text { Negative } \\
(2018.05 .02)\end{array}$ & \\
\hline & $2+(2018.05 .21)$ & \\
\hline \multirow[t]{4}{*}{ Ketone bodies } & $4+(2018.04 .25)$ & Negative \\
\hline & $1+(2018.04 .26)$ & \\
\hline & $\begin{array}{l}\text { Negative } \\
\qquad(2018.05 .02)\end{array}$ & \\
\hline & $\begin{array}{l}\text { Negative } \\
\quad(2018.05 .21)\end{array}$ & \\
\hline \multirow[t]{4}{*}{ Bacteria } & $\begin{array}{l}6776 / \mu \mathrm{l} \\
\quad(2018.04 .25)\end{array}$ & $0-385.8 / \mu \mathrm{l}$ \\
\hline & $\begin{array}{l}2416 / \mu \mathrm{l} \\
\quad(2018.04 .26)\end{array}$ & \\
\hline & $\begin{array}{l}1341 / \mu \mathrm{l} \\
(2018.05 .02)\end{array}$ & \\
\hline & $\begin{array}{l}186 / \mu \mathrm{l} \\
\quad(2018.05 .21)\end{array}$ & \\
\hline
\end{tabular}


Table 1 continued

\begin{tabular}{|c|c|c|}
\hline Test & Result (date) & Normal range \\
\hline \multirow[t]{4}{*}{ WBC } & $\begin{array}{l}50.9 / \mathrm{HP} \\
\quad(2018.04 .25)\end{array}$ & $0-4.5 / \mathrm{HP}$ \\
\hline & $\begin{array}{l}368.5 / \mathrm{HP} \\
(2018.04 .26)\end{array}$ & \\
\hline & $\begin{array}{l}1059.8 / \mathrm{HP} \\
(2018.05 .02)\end{array}$ & \\
\hline & $\begin{array}{l}\text { 16.8/HP } \\
(2018.05 .21)\end{array}$ & \\
\hline Blood glucose & $\begin{array}{r}25.03 \mathrm{mmol} / \mathrm{l} \\
(2018.04 .25)\end{array}$ & $3.9-6.11 \mathrm{mmol} / \mathrm{l}$ \\
\hline Glycated albumin & $33.58 \%$ & $11-16 \%$ \\
\hline $\begin{array}{l}\text { Glycated } \\
\text { hemoglobin }\end{array}$ & $6.9 \%$ & $4.8-6.0 \%$ \\
\hline \multicolumn{3}{|l|}{ C-peptide } \\
\hline Fasting & $0.28 \mathrm{ng} / \mathrm{ml}$ & $0.78-5.19 \mathrm{ng} / \mathrm{ml}$ \\
\hline $\begin{array}{l}60 \text { mins after } \\
\text { meal }\end{array}$ & $0.41 \mathrm{ng} / \mathrm{ml}$ & - \\
\hline $\begin{array}{l}120 \text { mins after } \\
\text { meal }\end{array}$ & $0.38 \mathrm{ng} / \mathrm{ml}$ & - \\
\hline $\begin{array}{l}\text { Type } 1 \text { diabetes } \\
\text { autoantibody } \\
\text { series }\end{array}$ & $\begin{array}{l}\text { GAD, IA2A, } \\
\text { ZnT-8A, ICA, } \\
\text { IAA } \\
\text { All negative }\end{array}$ & Negative \\
\hline $\begin{array}{l}\text { Antinuclear } \\
\text { antibody series }\end{array}$ & All negative & Negative \\
\hline
\end{tabular}

particularly prevalent in East Asia such as Japan, South Korea, Philippines, and China, while cases are rarely found in Caucasians and Native Americans with no seasonal or regional variations. Former reports showed that the prevalence of fT1D in Japan is about $19.4 \%$ of patients with T1D ketoacidosis. The incidence of fT1D in newly diagnosed T1D patients is $7.1 \%$ in Korea and about $1.5-5.45 \%$ in China [3]. Koga et al. confirmed that the ratio of serum glycated albumin to glycated hemoglobin (GA/ HbA1c) was significantly elevated in the early stage of fT1D. The cutoff value of 3.2 can generate $97 \%$ sensitivity and $98 \%$ specificity for distinguishing between fT1D and type 2 diabetes. Compared with GA or HbA1c, GA/HbA1c can better reflect short-term glycemic fluctuations in fT1D patients [4].

The pathogenesis of fT1D is still unclear while class II HLA is closely related to fT1D. Kwak et al. found that HLA DRB ${ }^{*} 04: 05$ $D Q B 1{ }^{*} 04: 01$ haplotype was significantly associated while histidine residues at HLA-DR $\beta 113$ were less associated with increased risk of fT1D in Korean patients [5]. CD $4^{+} \mathrm{CD} 45 \mathrm{RA}^{-} \mathrm{FoxP}^{\text {high }}$ activated regulatory $\mathrm{T}$ cells play an important role in $\mathrm{T}$ cell-mediated immune responses and are impaired in both fT1D and autoimmune type 1 diabetes (T1AD) patients with large numbers of infiltrating $\mathrm{T}$ cells and macrophages in the pancreas [6]. Haseda et al. found that anti-CD300e antibody is a novel biomarker that can help diagnose fT1D [7]. Wang et al. found that the expression of IFN- $\gamma$ significantly increased in peripheral blood mononuclear cells of fT1D patients indicating that autoimmune responses are related to fT1D in Chinese patients [8]. Nagafuchi et al. found that TYK2 mutation may be associated with the susceptibility of virus-induced fT1D with flu-like symptoms, and the risk of anti-GAD antibodynegative patients significantly increased compared with anti-GAD antibody-positive patients [9]. The occurrence of fT1D during pregnancy accounts for $34.6 \%$ of all female T1D patients which contributes to the poor maternal and fetal prognosis. If not promptly treated, an increased risk of complications with about $88.9 \%$ of chance of having a stillbirth may happen [10]. Japan has reported a number of patients who developed fT1D after anti-PD-1 drug therapy, which may be due to inappropriate activation of $\mathrm{T}$ cells in a population of HLA haplotype DRB1*04:05-DQB1*04:01 [11-13].

Decreased endogenous insulin secretion leads to fluctuations in blood glucose and sudden increase in blood glucose can lead to complications of microvascular disease in fT1D patients. However, Hiroko et al. found there is no significant difference in the incidence of microvascular complications between fT1D patients and non-fT1D patients because early 
Anti-nuclear antibody series

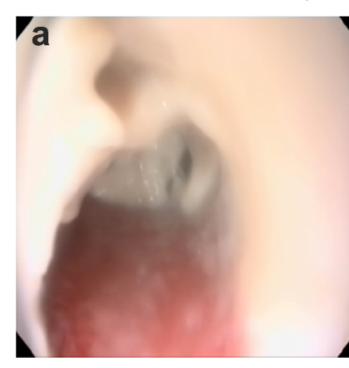

All Negative

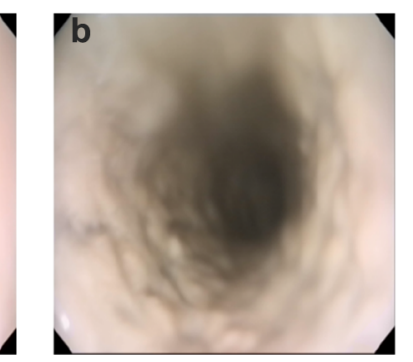

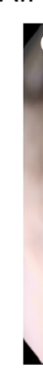

Negative

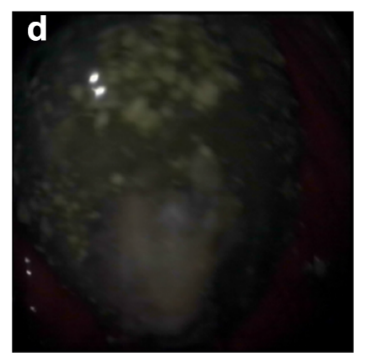

Fig. 1 Gastroscopy images of upper esophagus (a), middle esophagus (b), esophageal cardia (c), and gastric fundus (d) before treatment
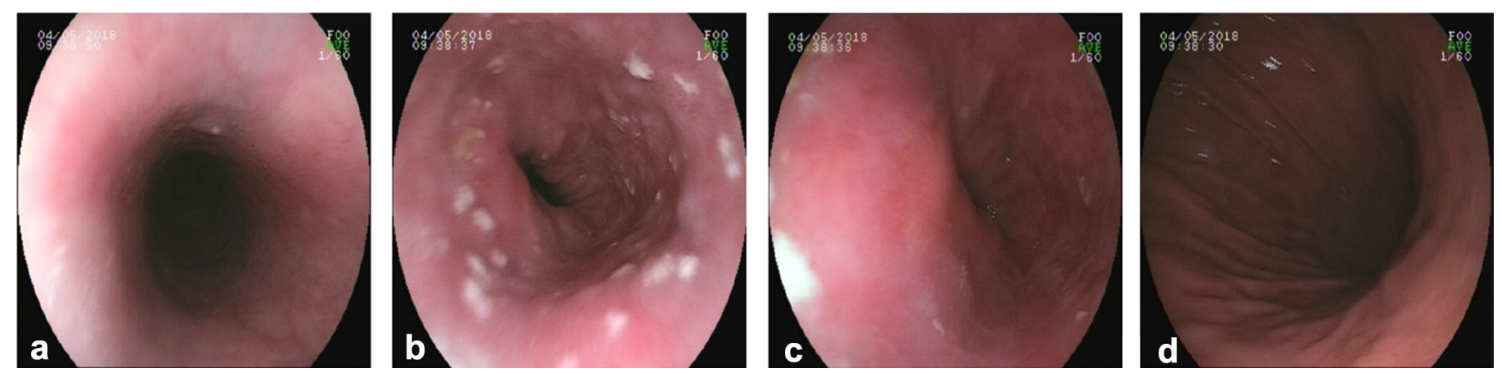

Fig. 2 Gastroscopy images of upper esophagus (a), middle esophagus (b), esophageal cardia (c), and gastric fundus (d) after treatment
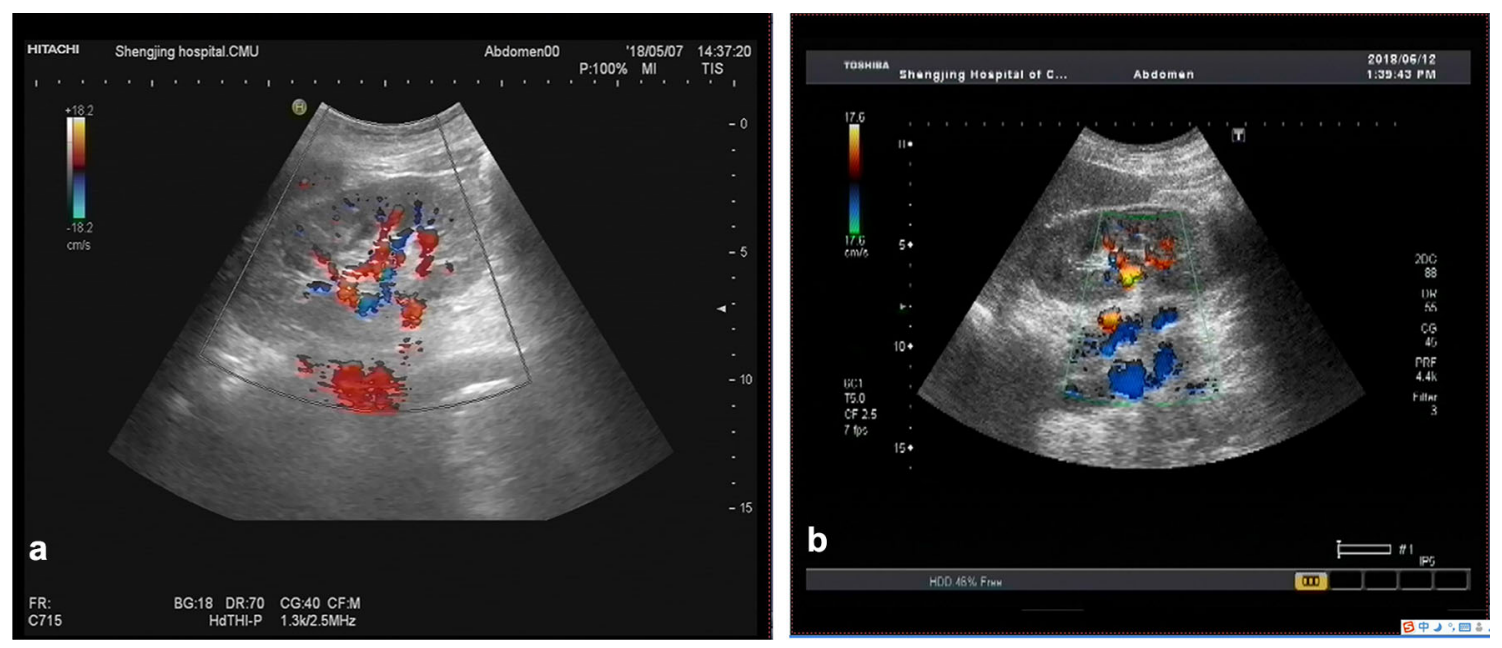

Fig. 3 Ultrasound images of bladder before (a) and after (b) treatment

intensive glycemic control may effectively prevent microvascular complications [14]. With significantly higher titers of immunoglobulin A and coxsackievirus, poliovirus, and echovirus, the occurrence of renal insufficiency in patients with fT1D was significantly higher than nonfT1D patients because enterovirus is the causative factor of glomerulonephritis which can lead to the high risk of renal insufficiency in patients with fT1D [15]. Gastroparesis is often secondary to diabetes, and is characterized by delayed gastric emptying without significant structural abnormalities accompanied with chronic nausea and vomiting, early satiety, 
postprandial fullness, and stomachache [16]. It is not only related to irreversible diabetic autonomic neuropathy but also to the loss of interstitial cells of Cajal or dysfunction or insufficient neurotransmission. Furthermore, short-term hyperglycemia can also slow down gastric emptying [17]. Diabetic genital autonomic neuropathy can cause dysuria and urinary retention, which greatly increases the risk of urinary tract infections [18].

Patients with fT1D are often diagnosed with ketoacidosis whose acute phase should be treated by intravenous injection of small doses of conventional insulin and intravenous rehydration. After ketoacidosis is corrected, multiple subcutaneous insulin injections or continuous subcutaneous insulin infusion should be given immediately. Imagawa et al. found that insulin doses for fT1D patients were $0.7-0.8 \mathrm{U} / \mathrm{kg} /$ day, which is higher than $0.5-0.6 \mathrm{U} / \mathrm{kg} /$ day for T1AD patients. The difference of initial insulin dose between fT1D patients $(0.63 \pm 0.22 \mathrm{U} / \mathrm{kg} /$ day $)$ and non-fT1D patients $(0.43 \pm 0.21 \mathrm{U} / \mathrm{kg} /$ day $)$ did not show a statistically different microvascular complication rate between fT1D and non-fT1D patients [19]. Glucagon-like peptide I (GLP-1) receptor agonists have been reported to decrease cell destruction and prevent viral-induced diabetic myocarditis. Together with continuous glucose monitoring, the occurrence and development of microvascular complications in fT1D patients can be reduced [20].

In conclusion, although cases of fT1D have already been published since the original description, few were accompanied with severe autonomic nervous disorders such as gastric retention and urinary retention. The GA/HbA1c of the patient was 4.87, indicating a short course of disease with a significant fluctuation of blood glucose. Although the C-peptide level was low, the reason for the residual beta cell function in this case may be a result of timely intensive insulin therapy in the early stages of the disease. Although the patient's course is extremely short, she had severe autonomic nervous disorder such as gastric retention, urinary retention, and rapid onset of serious diabetic peripheral neuropathy, binocular diabetic retinopathy, and diabetic nephropathy within
1 month after the onset of ketoacidosis which were not consistent with the course of the disease. After treatment, the patient's autonomic nervous disorder and local infection were quickly improved. However, the patient's islet secretion function was severely impaired with largely fluctuating blood glucose and asymptomatic hypoglycemia occurred repeatedly. This case highlights that we should pay more attention not only aim to control blood glucose fluctuation effectively but also to whether there are existing chronic complications, so that appropriate treatment can be given as soon as possible to improve the long-term prognosis of patients.

\section{ACKNOWLEDGEMENTS}

We thank the participants of the study.

Funding. No funding or sponsorship was received for this study or publication of this article. The article processing charges were funded by the authors.

Authorship. All named authors meet the International Committee of Medical Journal Editors (ICMJE) criteria for authorship for this article, take responsibility for the integrity of the work as a whole, and have given their approval for this version to be published.

Disclosures. All the authors (Chuan Xing, Wenqian Zhao, and Yanjun Wang) declare that they have no conflicts of interest regarding the publication of this paper.

Compliance with Ethics Guidelines. Informed consent was obtained from the individual participant for being included in the study.

Open Access. This article is distributed under the terms of the Creative Commons Attribution-NonCommercial 4.0 International License (http://creativecommons.org/licenses/ by-nc/4.0/), which permits any noncommercial use, distribution, and reproduction in any medium, provided you give appropriate 
credit to the original author(s) and the source, provide a link to the Creative Commons license, and indicate if changes were made.

\section{REFERENCES}

1. Imagawa A, Hanafusa T, Miyagawa J, et al. A novel subtype of type 1 diabetes mellitus characterized by a rapid onset and an absence of diabetes-related antibodies. N Engl J Med. 2000;342(5):301-7. https://doi.org/10.1056/NEJM200002033420501.

2. Imagawa A, Hanafusa T, Awata T, et al. Report of the Committee of the Japan Diabetes Society on the research of fulminant and acute-onset type 1 diabetes mellitus: new diagnostic criteria of fulminant type 1 diabetes mellitus. J Diabetes Investig. 2012;3(6):536-9. https://doi.org/10.1111/jdi.12024.

3. Park Y, Wintergerst KA, Zhou Z. Clinical heterogeneity of type 1 diabetes(T1D) found in Asia. Diabetes Metab Res Rev. 2017;33(7). https://doi. org/10.1002/dmrr.2907.

4. Koga $\mathrm{M}$, Inada $\mathrm{S}$, Nakao $\mathrm{T}$, et al. The glycated albumin (GA) to HbA1c ratio reflects shorter-term glycemic control than GA: analysis of patients with fulminant type 1 diabetes. J Clin Lab Anal. 2017;31(1). https://doi.org/10.1002/jcla.22023.

5. Kwak SH, Kim YJ, Chae J, et al. Association of HLA genotype and fulminant type 1 diabetes in Koreans. Genom Inform. 2015;13(4):126-31. https://doi.org/ 10.5808/GI.2015.13.4.126.

6. Haseda F, Imagawa A, Murase-Mishiba $\mathrm{Y}$, et al. $\mathrm{CD}^{+}{ }^{-} \mathrm{CD}_{45 \mathrm{RA}^{-} \text {FoxP3 }}{ }^{\text {high }}$ activated regulatory $\mathrm{T}$ cells are functionally impaired and related to residual insulin-secreting capacity in patients with type 1 diabetes. Clin Exp Immunol. 2013;173(2):207-16. https://doi.org/10.1111/cei. 12116.

7. Haseda F, Imagawa A, Nishikawa H, et al. Antibody to CMRF35-like molecule 2, CD300e a novel biomarker detected in patients with fulminant type 1 diabetes. PLoS One. 2016;11(8):e0160576. https:// doi.org/10.1371/journal.pone.0160576.

8. Wang $\mathrm{Z}$, Zheng $\mathrm{Y}, \mathrm{Tu} \mathrm{Y}$, et al. Immunological aspects of fulminant type 1 diabetes in Chinese. J Immunol Res. 2016;2016:1858202. https://doi. org/10.1155/2016/1858202.
9. Nagafuchi S, Kamada-Hibio Y, Hirakawa K, et al. TYK2 promoter variant and diabetes mellitus in the Japanese. EBioMedicine. 2015;2(7):744-9. https:// doi.org/10.1016/j.ebiom.2015.05.004.

10. Yoneda S, Imagawa A, Fukui K, et al. A histological study of fulminant type 1 diabetes mellitus related to human cytomegalovirus reactivation. J Clin Endocrinol Metab. 2017;102(7):2394-400. https:// doi.org/10.1210/jc.2016-4029.

11. Luo S, Zhang Z, Li X, et al. Fulminant type 1 diabetes: a collaborative clinical cases investigation in China. Acta Diabetol. 2013;50(1):53-9. https://doi. org/10.1007/s00592-011-0362-1.

12. Okamoto M, Gotoh $\mathrm{K}$, Masaki $\mathrm{T}$, et al. Fulminant type 1 diabetes mellitus with anti-programmed cell death-1 therapy. J Diabetes Investig. 2016;7(6):9158. https://doi.org/10.1111/jdi.12531.

13. Miyoshi Y, Ogawa O, Oyama Y. Nivolumab, an anti-programmed cell death-1 antibody, induces fulminant type 1 diabetes. Tohoku J Exp Med. 2016;239(2):155-8. https://doi.org/10.1620/tjem. 239.155 .

14. Takaike H, Uchigata $Y$, Nakagami T, et al. Incidence and development of diabetic microangiopathy of fulminant type 1 diabetes-comparison with nonfulminant type 1 diabetes. Intern Med. 2010;49(12):1079-83.

15. Takahashi N, Tsujimoto T, Chujo D, et al. High risk of renal dysfunction in patients with fulminant type 1 diabetes. J Diabetes Investig. 2018;9(1):146-151. https://doi.org/10.1111/jdi.12652.

16. Pasricha PJ, Yates KP, Nguyen L, et al. Outcomes and factors associated with reduced symptoms in patients with gastroparesis.Gastroenterology. 2015;149(7):1762-1774.e4. https://doi.org/10.1053/ j.gastro.2015.08.008.

17. Chang J, Russo A, Bound M, et al. A 25-year longitudinal evaluation of gastric emptying in diabetes. Diabetes Care. 2012;35(12):2594-6. https://doi.org/ $10.2337 /$ dc12-0028.

18. Van Den Eeden SK, Sarma AV, Rutledge BN, et al. Effect of intensive glycemic control and diabetes complications on lower urinary tract symptoms in men with type 1 diabetes: Diabetes Control and Complications Trial/Epidemiology of Diabetes Interventions and Complications (DCCT/EDIC) study. Diabetes Care. 2009;32(4):664-70. https:// doi.org/10.2337/dc07-2375. 
19. Liu L, Zeng L, Sang D, et al. Recent findings on fulminant type 1 diabetes[J].Diabetes Metab Res Rev. 2018;34(1). https://doi.org/10.1002/dmrr. 2928.
20. Shibasaki S, Imagawa A, Hanafusa T. Fulminant type 1 diabetes mellitus: a new class of type 1 diabetes. Adv Exp Med Biol. 2012;771:20-3. 